\title{
SPUR GEARS WITH LONGITUDINAL TOOTH PROFILE MODIFICATION MESH CREATING WHICH IS SUITABLE FOR STRESS ANALYSIS
}

\author{
Michal Sobiepański, Tadeusz Nieszporek
}

Original scientific paper

Presented article contains description of meshing procedure applied by authors for preparation of discrete spur gears models used in stress analysis with ABAQUS computer program. Described procedure was successfully applied for meshing of single spur gear sector crown. This sector includes one tooth and two parts of side tooth spaces. Such form of mesh allows to build models including any part of spur gear crown up to full one. Sector based structure of the discrete domain allows to reduce the computation time. Developed special computer program based on presented procedure is a fully functional tool and allows fast preparation of meshes for different set of parameters describing spur gear geometry inclusive longitudinal tooth profile modifications. All meshes presented in this article were prepared with developed by authors mesh generator.

Keywords: finite element analysis; spur gears; tooth modification

Formirana mreža čelnika s modifikacijom uzdužnog profila zubi koja je pogodna za analizu naprezanja

Izvorni znanstveni članak

U radu se daje opis postupka umrežavanja koji su autori primijenili u pripremi modela čelnika korištenih u analizi naprezanja primjenom računalnog programa ABAQUS. Opisani postupak uspješno je primijenjen kod umrežavanja tjemena čelnika s jednostrukim zahvatom. Taj dio uključuje jedan zub i dva dijela bočnih prostora zubi. Takav oblik mreže omogućava izgradnju modela koji uključuju bilo koji dio tjemena čelnika do cijelog zupčanika. Konstrukcija diskretnog područja omogućava smanjenje vremena izračuna. Specijalni računalni program razvijen opisanim postupkom potpuno je funkcionalni alat i omogućuje brzu pripremu mreža za različit niz parametara koji opisuju geometriju čelnika uključujući modifikacije uzdužnog profila zubi. Sve mreže predstavljene u ovom radu pripremljeni su s generatorom mreže koji su razvili autori.

Ključne riječi: analiza konačnih elemenata; čelnici; modifikacija zuba

\section{New spur gear manufacturing technology causes the development of special meshing tool}

Spur gears are widely used parts in machines. New manufacturing technologies based on CNC machine tools allow manufacturing of spur gears with tooth profile modifications unavailable or hard to achieve with standard technologies. Such standard technologies are based on hobbing or shape methods $[1,2]$. Gear hobbing remains a cutting technology mainly dedicated to largescale productions of gears for the automotive industry. During hobbing special and expensive tools are used [3, 4]. Special machines are necessary too. Such technology is effective in long series production. Second, older method may be applied with standard horizontal milling machine equipped with dividing head. The tool is then cheaper (disk spur gear milling cutter) but the manufacturing efficiency is low. Second method may be applied for manufacturing of short series or for special gears - special tool may be prepared for example with application of multi axis $\mathrm{CNC}$ machine tool. Introduction of tooth profile modifications for spur gears manufactured with application of listed above methods requires the use of additional machining, realised on additional machine, with application of additional tools (cutters or grinding wheels). The facts presented above show that traditional manufacturing technologies are ineffective for spur gear manufacturing with tooth profile modifications. Such problem may be solved by the application of multi axis CNC machine tools $[5,6]$. The technology of cutting spur gears by machining with the step-by-step method on universal CNC machine tools is available. The cutting tool is a ball-end finger-type mill, whose geometry is not associated with the geometry of the toothing being cut, which makes it a universal and cheap tool. The developed technology enables the longitudinal and transverse modification of the tooth profile. It can be useful especially in the machining of gears in piece and small-lot production and large-module gears with tooth modification. Special computer program dedicated for code preparation for $\mathrm{CNC}$ machine tool was developed and tested $[7,8]$. Obtained results show that the method is a real alternative for classical manufacturing methods and should be further developed. Because manufacturing of modified spur gears is possible and its application in industrial manufacturing of such parts seems to be real, the method of numerical analysis of stresses in gears manufactured in such way will be necessary for optimisation of spur gears design. This analysis method (Finite Element Method) makes it possible to analyze contact area and maximum stress at the same time. Using this method, it is possible to determine the optimal tooth shape. This fact was the reason why authors devoted their work for developing a special meshing computer program improving the efficiency during preparation of discrete models of spur gears with special geometry features being the result of tooth profile modification. Improvement of exploitation features such as lower noise and longer durability should be the results of complex manufacturing method based on numerical computations and experiments [9-16].

\section{The geometry of spur gear tooth with longitudinal profile modification}

The geometry of spur gear tooth profile is based on involute curve. Involute curve is the trace of the end point of the wire unwounded from the circle called the base 
circle. Every spur gear has some characteristic parameters [1]. The most important are: module, number of teeth, pitch, pitch circle diameter, base circle diameter, addendum diameter, addendum height, dedendum height, face width, clearance, fillet radius, circular thickness and backlash. If listed parameters have defined values the geometry of the spur gear is fully described and the model of the gear may be prepared in any CAD program. Prepared discrete model of the gear may be imported into selected analysis software for example into ABAQUS [17] used by authors of this article. This method seems not to be effective when spur gear teeth faces are modified. Introduction of additional surfaces for modification of face geometry is complex. Moreover the resulting geometry may be imprecise after loading into analysis software. The volume of the model may be ajar and some geometry repair may be expected. The idea of longitudinal tooth profile modification is presented in Fig. $1[7,8,18,19]$. The modification is the sagitta (versine) of the arc created from the circle of radius $(\rho)$ by the chord with the length $(b)$ - tooth length. The value of the modification can change on the height of the tooth of the spur gear.

a)

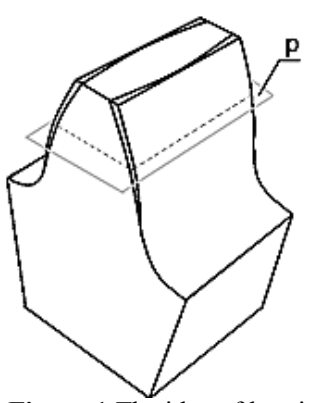

Figure 1 The idea of longitudinal tooth profile modification. The tooth face is rounded at the whole

Presented tooth shape may be obtained during machining on CNC machine tools. Developed computer program [6] gives support for CNC machine tool code preparation. The goal of the work presented here was to develop a special computer program supporting the preparation of finite element meshes, necessary for numerical analysis of stresses in spur gears with longitudinal tooth profile modifications. The most important features of the program may be listed as follows:

- program should generate files ready to be imported by the ABAQUS program,

- the generated file should include complete model of the mesh inclusive single sector of the spur gear crown,

- some additional features (such as additional instances of meshed gear sections) helpful for preparation of simulation in ABAQUS program may be included in the generated file,

- the opportunity to prepare the mesh for spur gears with longitudinal tooth profile modification is expected.

The code was written in $\mathrm{C}++$ and compiled with GCC compiler-linker tool kit in Linux operating system [8].

\section{The structure of generated finite element mesh}

Authors decide to use the meshing procedure based on the rigidly defined mesh structure defined by some parameters describing the mesh of plain tetragonal elements generated for the cross-section of discretized area. Such method allows simple access to mesh nodes when their primary position should be changed for introduction of such features as fillet, boundary layer with defined depth or longitudinal tooth face modification. Parameters necessary for generation of the mesh may be divided in two groups. First group includes parameters describing the geometry of the discretized profile border: module, base circle diameter, number of teeth, clearance, backlash, pressure angle. If values of listed parameters are given, the coordinates for mesh nodes lying on the order may be calculated. The number of such nodes depends of the predefined structure of expected mesh. The second group of parameters used for definition of this structure is (visualisation in Fig. 3):

1) number of element rows generated for the space between hub hole radius and the root radius, - NRR (Fig. 2c)

2) number of element rows generated for the space between root radius and base circle radius - NRC (Fig. 2b),

3) number of element rows generated for the space between base circle radius and addendum radius NRT (Fig. 2a),

4) number of element columns in the region of tooth root - NCT, (Fig. 2c)

5) number of element columns for the spaces beside the tooth root space - NCS (Fig. 2d).

Summing, the mesh structure is defined by number of rows and columns of elements generated for subregions of discretized area. The idea of discretized area division is presented in Fig. 2. Presented mesh does not include the fillet between tooth and the root. Introduction of the fillet is done not by generation of additional element but by relocation of nodes lying on the profile border between common points of fillet arc and this border. a)

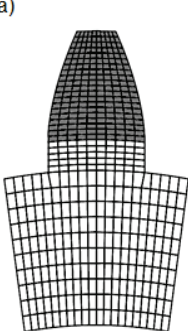

b)

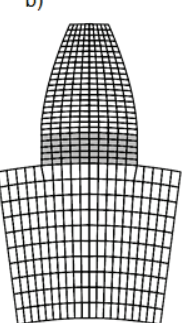

c)

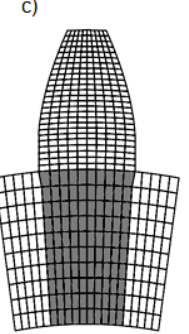

d)

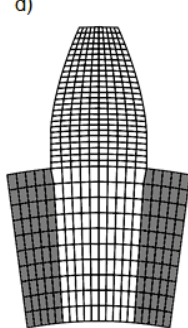

Figure 2 Groups of tetragonal elements generated for cross-section: a) elements in the tooth cross-section, b) elements in the connecting region,

c) elements in the root under the tooth, d) side elements of the root

The parameters describing mesh presented in Fig. 2 are: $\mathrm{NRR}=10, \mathrm{NRC}=5, \mathrm{NRT}=20, \mathrm{NCT}=10, \mathrm{NCS}=10$.

If the value of the fillet radius is given coordinates of its contact points with profile border may be calculated and nodes lying on the border between contact points may be relocated. In such way the fillet is introduced into the mesh (Fig. 3).

Last operation before formulation of cubic elements 
is relocation of nodes lying under the top border of the profile, where some effects of heat treatment may be considered. Nodes should be relocated and their new coordinates are calculated using the value of boundary layer width.

Plain mesh in the form presented in Fig. 4 is the base for creating the spatial mesh of cubic elements. For the analysis, element of type C3D8R [17] was selected. When the number of parallel mesh planes normal to spur gear axis is given, the distance between planes ( $Z$ coordinates for nodes lying on plane) may be calculated as factors of face width. Spatial mesh sample consists of C3D8R elements and based on plain meshes presented in previous figures is presented in Fig. 5.
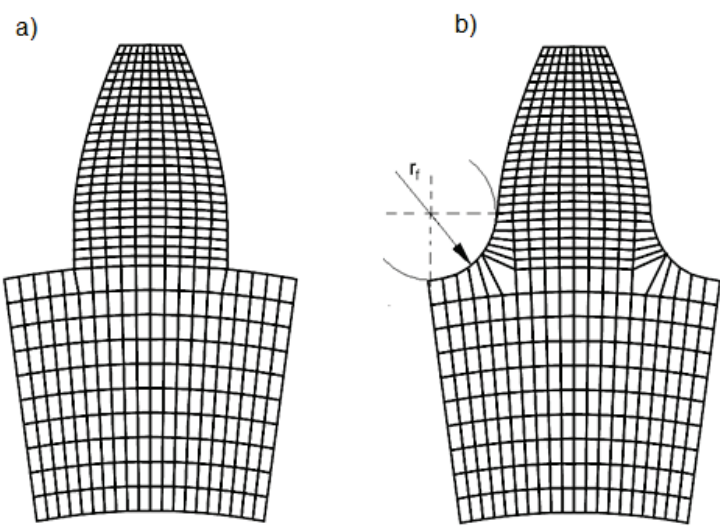

Figure 3 Introduction of fillet into the generated mesh (a) by relocating previously generated mesh nodes (b) a)

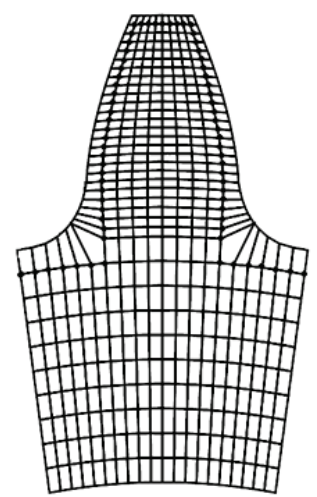

b)

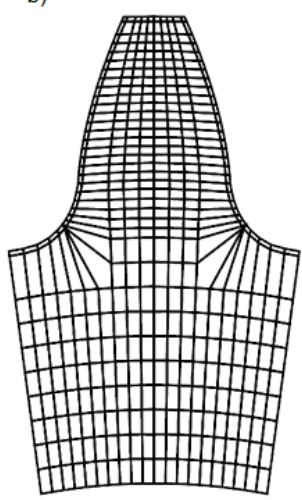

Figure 4 The structure of the generated mesh represented by rows and columns of elements a)

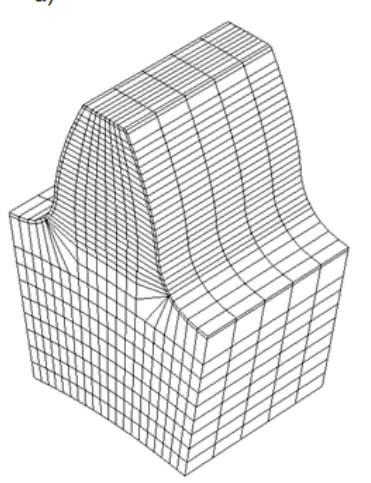

b)

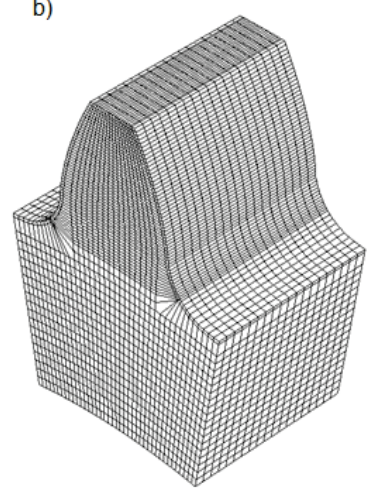

Figure 5 Comparison of two sample spatial meshes of C3D8R elements based on the plane meshes distributed in equal distances along the axis of spur gear: a) 2250 elements and 3036 nodes; b) 34200 elements and 38220 nodes
Last operation performed on generated spatial mesh is introduction of longitudinal profile modification. This operation may be performed only on spatial mesh, when all nodes lying on the tooth face are present. Two meshes, one without longitudinal tooth profile modification and the second one with such modification are shown in Fig. 6 . The value of modification parameter was $f=0.1 \mathrm{~mm}$ only to improve the visibility of the modification influence on the shape of generated mesh. a)

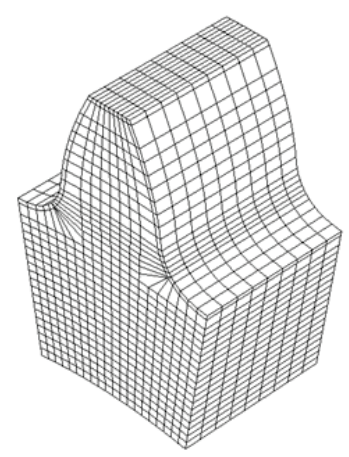

b)

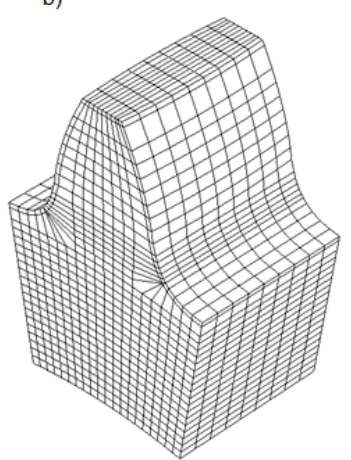

Figure 6 The visualisation of the longitudinal tooth profile modification (b) introduced into base spatial mesh (a) by relocating mesh nodes lying on the tooth face

\section{Building the model based on single sector meshes}

Performed sector meshes may be imported into ABAQUS as model file (*.inp) because their structure is saved acceptable by ABAQUS form. After importing the model into ABAQUS sectors may be cloned with Radial pattern tool and connected together with Tie tool. The generated model file is plain text file with precisely defined structure divided in data blocks. The definition of such file may be found in ABAQUS user manuals rich in example model files. In Figure 7 sample model of two partial spur gear crowns is presented.

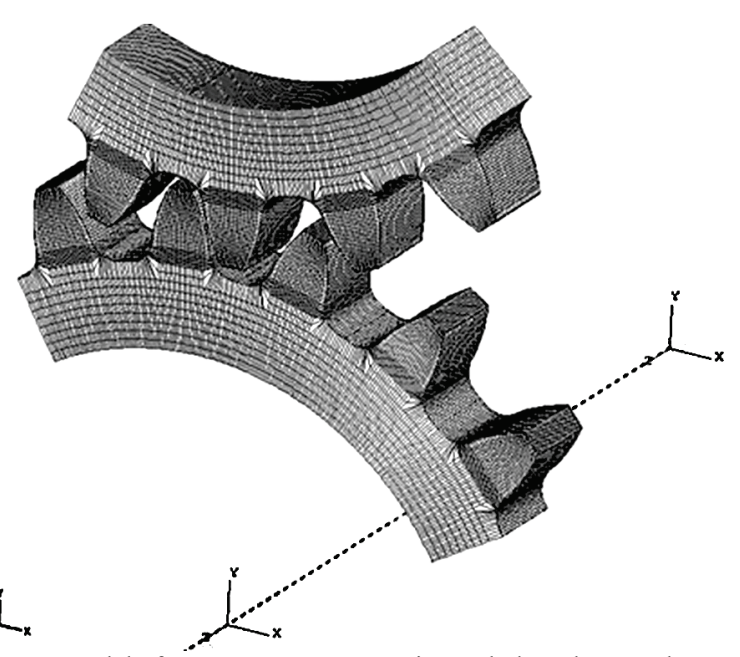

Figure 7 Model of two spur gear crowns in mesh, based on mesh sectors prepared in computer program developed by authors

\section{Conclusions}

Spur gear geometry, when some tooth profile modifications are introduced, may cause problems with its discretization with CAD programs. Preparation of meshes necessary for finite element analysis may be 
successfully supported by special computer programs developed specially for such narrow application. Presented results show that preparation of meshes without preparation of discrete geometry models in CAD programs is the right way. Developed program needs further work. Additional element types may increase the mash quality especially in regions where after modification of initially performed mesh internal angles between element edges become too small. Tetrahedral elements may be desired in boundary layer regions to improve the conditions of contact between teeth surfaces.

\section{References}

[1] Litvin, F. L.; Fluentes, A. Gear geometry and applied theory. Cambridge University Press, Cambridge, 2004. https://doi.org/10.1017/CB09780511547126

[2] Nieszporek, T. Podstawy konstrukcji narzędzi skrawających do obróbki walcowych uzębień zewnętrznych. Czestochowa University of Technology, Czestochowa, 2004.

[3] LMT FETTE. Verzahnungswerkzeug fur die Windkraftindustrie. Gear cutting tools in the wind power industry. Printed in Germany, No. 2122 (0908 1 DM/GK).

[4] FETTE. Verzahnungswerkzeuge. Wallzfrasen. Zahnformfrasen. Printed in Germany, No. 1577 (603 2 DTP/GK).

[5] MAZAK. Przyszłość twojej produkcji. General Catalogue, 201212.031500 T 99J644812EO.

[6] DMG ELECTRONIX. CTX Technology Cycles. Shop Turn $3 \mathrm{G}$ User Interface. DMG/MORI SEIKI PRO.SD5582 0512UK.

[7] Nieszporek, T.; Sobiepański M. The Manufacturing Technology for Spur Gears with Tooth Profile Modifications. Profile Modifications in Mesh. // Academic Journal of Manufacturing Engineering. Brasov, 10, 4(2012), pp. 92-97.

[8] Sobiepański, M.; Nieszporek, T. Numerical Analysis of Spur Gears with Longitudinal Tooth Profile Modification in Mesh. // Academic Journal of Manufacturing Engineering. Brasov, 10, 3(2012), pp. 103-108.

[9] Kawalec, J.; Wiktor, A. Form and strength properties of spur gear tooth root with consideration of technological factors. // Advances in Manufacturing Science and Technology. Polish Academy of Sciences. 25, 1(2001), pp. 35-37.

[10]Ihwan, Sseol; Soonbae, Chung. Simulation of meshing for the spur gear drive with modified tooth surfaces. // KSME International Journal. 14, 5(2000), pp. 490-498. https://doi.org/10.1007/BF03185651

[11] Gyenge, Cs.; Boca, V.; Muresan, A. Some technological aspects of high precision worm-gear manufacturing. // Journal of Manufacturing Engineering Duplement. 1(2008), pp. 154-159.

[12] Olah, L.; Gyenge, Cs.; Boca, V. New hobbing tools with alternative cutting for spur gears finishing. // Annals of MteM for 2009 \& Proceedings of the 9th International MteM Conference. Published by MteM 2009, Editor Cs. Gyenge / Cluj-Napoca, 2009, pp. 213-216.

[13]Bouzakis, K.-D.; Lili, E,; Michailidis N.; Friderikos, O. Manufacturing of cylindrical gears by generating cutting process: A critical synthesis of analysis methods. // CIRP Journal of Manufacturing Science and Technology. 75 (2002), pp. 676-696.

[14] Bouzakis, K-D.; Kombpgianis, S.; Antoniadis, A.; Vidalis, N. Gear Hobbing Cutting Process Simulation and Tool Wear Prediction Models. // Journal of Manufacturing Science and Engineering. 124(2002), pp. 42-51. https://doi.org/10.1115/1.1430236
[15]Dimitriou, V.; Antoniadis, A. CAD-based simulation process for the manufacturing of spur and helical gears. // The International Journal of Advanced Manufacturing Technology. 411(2009), pp. 347-355. https://doi.org/10.1007/s00170-008-1465-x

[16] Hassan, A. R. Contact Stress Analysis of Spur Gear Teeth Pair. // World Academy of Science, Engtineering and Technology. 34(2009), pp. 611-616.

[17] Abacus user's manual available in electronic form as a part of ABAQUS environment after installation.

[18]Bob, M.; Bob, D. Aspects regarding profile modification of spur gears. // Annals of MteM for 2011 \& Proceedings of the 10th International MteM Conference. Published By MteM, Editor Cs. Gyenge / Cluj-Napoca, 2011, pp. 29-32.

[19] Dimitrov, L.; Yordanova, S.; Dimchev, G. Reduction of noise in involute gear couples by addendum modification. // Academic Journal of Manufacturing Engineering. 1(2008), pp. $57-62$

\section{Authors' addresses}

Michal Sobiepański, PhD. MSc. Eng.

Czestochowa University of Technology

Armii Krajowej 21, 42-201 Częstochowa, Poland

E-mail: sobiepanski@wimii.pcz.pl

Tadeusz, Nieszporek, Prof. DSc. PhD. MSc. Eng Czestochowa University of Technology Armii Krajowej 21, 42-201 Częstochowa, Poland E-mail: tadek@itm.pcz.czest.pl 